\title{
Improving the capacity of the head of the sub civil service in regional apparatus organisation of the government in Malaka district
}

Oliva Bria Seran ${ }^{1 *}$, M. N. B. C. Neolaka ${ }^{2}$, Frans Gana ${ }^{3}$

The Malaka Officialdom and Human Resources Development Agency, Malaka, Indonesia ${ }^{1 *}$ Public Administration Study Program, Nusa Cendana University, Kupang, Indonesia ${ }^{2,3}$ briaseran676@gmail.com ${ }^{1 *}$, neolakamelkisedek16@ gmail.com ${ }^{2}$, frans gana@yahoo.co.id ${ }^{3}$

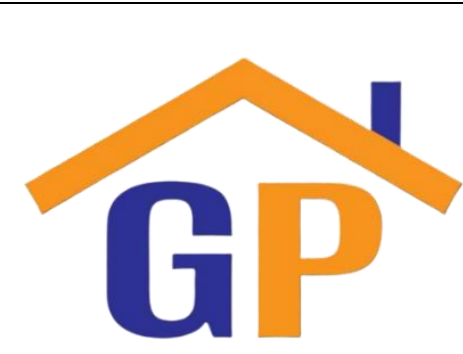

Article History

Received on 4 August 2020

$1^{\text {st }}$ Revision on 20 December 2020

$2^{\text {nd }}$ Revision on 29 December 2020

Accepted on 5 January 2021

\begin{abstract}
Purpose: The purpose of this study was to examine the human resource capacity of the Head of Personnel Subdivision in the Organization of the Scope of the Malaka Regency Government, to find out supporting factors and constraints of the Human Resources Capacity its function and to find out the efforts taken by the Organization of the Regional Government of the Malaka Regency in increasing the capacity of Human Resources Head of Personnel Sub Division.
\end{abstract}

Research methodology: The research method used in research was qualitative research methods with the type of case studies.

Results: This study's results are that human resource capacity is inadequate due to the low educational qualifications held by the Head of Personnel Sub-division within the scope of the Malaka district government.

Limitation: This study's limitation is that this research only focuses on the phenomena in the Malaka Regency so that the results of similar research can produce different findings if carried out on other research objects.

Contribution: This research's contribution is that it can provide scientific information for students of public administration programs and can be a scientific reference in the formulation and development of civil service innovations within the local government of Malaka Regency.

Keywords: Capacity, Regional apparatus organization

How to cite: Seran, O. B., Neolaka, M. N. B. C., Gana, F. (2021). Improving the capacity of the head of the sub civil service in regional apparatus organisation of the government in Malaka district. Journal of Governance and Accountability Studies, 1(1), $15-28$.

\section{Introduction}

In line with the implementation of the decentralisation system, where the government has given great authority to the regions to carry out various government affairs, various efforts have been made to develop local governments' capacity in the administration of government affairs through the development of Human Resources (HR). This aims to create regional governments that have a sustainable capacity in government administration so that the improvement of public welfare can be achieved effectively and efficiently.

In Law Number 32 of 2004, Article 33, which has been replaced by Law Number 23 of 2014 concerning Regional Government, states that regional authority in developing apparatus resources is carried out through career development, taking into account education and training. This shows that capacity building is always supported by education and training. 
At the same time, Regional Regulation Number 81 of 2016 concerning the Organization of the Regional Apparatus (OPD) of Malaka district is also as outlined in the Regulation of the Regent of Malaka Regency Number 81 of 2016 concerning Details of Duties, Functions and Work Procedures of the Malaka District Civil Service and Training Agency, Civil Service Agency, Education and Training in Malaka district also has the task of carrying out the formulation and regional policies in the field of Personnel, Education and Training and the implementation of functions, such as:

a) Formulating technical policies in the field of personnel and training.

b) Coordinating the formulation of policies in the field of employment, education and training.

c) Coaching and implementing duties in the field of personnel, education and training.

d) Implementing other duties assigned by the Regent in accordance with his function

Referring to the efforts to develop the duties, functions and work procedures of the Malaka Civil Service and Education and Training Agency, Hasibuan (2007: 69) defines development as an effort to improve the technical, theoretical, conceptual and moral abilities of employees according to the needs of the job / position through education and training (training). Education aims to improve the theoretical, conceptual and moral skills of employees, meanwhile, training aims to improve technical skills in the implementation of employee work. Hasibuan (2007: 72-73) also classifies the types of development into two, including:

a) Formal development means that the company assigns employees to attend education and training, both conducted by the company and by educational or training institutions. Because of current or future job demands, which are non-career in nature or an employee's career advancement, the company does this.

b) Informal development, namely employees have their own desires and efforts to train and develop themselves by studying literature books that have to do with work or position. This shows that these employees have a strong desire to move forward by increasing their work abilities.

Furthermore, in the effort to develop the capacity of the apparatus' resources, which should be supported by education and training, it can be seen some details of the duties and functions of the Head of the Sub Division of Personnel as described in the 2016-2021 BKPP RENSTRA of Malaka Regency (pp. 5-7) as following:

a) Planning activities in the Sub Division of Finance, General Affairs and Personnel based on the evaluation of the previous year as a reference for preparing the next year's activity plans in accordance with applicable regulations.

b) Dividing duties to subordinates according to their respective duties and responsibilities for the smooth implementation of the General Finance and Civil Service Subdivision duties.

c) Guiding the implementation of subordinate tasks in the General and Civil Service Subdivision in accordance with the duties and responsibilities given so that work runs smoothly and regularly.

d) Checking subordinates' work results based on the assigned tasks and responsibilities so that tasks can be completed on time and as expected.

e) Conducting staff meetings with all staff of the Education and Training Personnel Board.

f) Making outgoing/incoming letters and preparing guidelines and administrative guidelines for correspondence and archiving according to the administrative guidelines for correspondence and service archives and reporting on employee progress every month, quarter, semester.

g) Evaluating activities in the General Finance and Human Resources Sub-Section by comparing the plan with the activities that have been implemented for reporting the implementation of activities.

h) Reporting the implementation of duties in the General Finance and Personnel SubDepartment in accordance with the applicable procedures and regulations for 
accountability and future plans as well as carrying out other official duties given by superiors, both verbally and in writing.

The description of the Head of the Personnel Section's duties and functions above again emphasised that if the Head of the Personnel Sub Division's capacity is said to be good, then the quality of public services will get better. The conclusion is that capacity building will reduce the bureaucracy's pathological actions and reduce the pathological impact it causes, thereby improving the quality of public service delivery. Either directly or indirectly in a local government, the Head of Sub Division of Personnel is always required to be able to maximise the potential capacity they have; then this is applied directly to their main tasks and functions as servants who are responsive to the needs of the community (internal and external).

In line with the above, Ambar Teguh and Rosidah (2009: 252) also explain that, the most important element from within and from outside (internal - external) of a government organisation is its people or human resources. Because after all those who carry out the activities of an organisation are humans who are part of the organisation. Therefore, to answer various problems in the organisation, development efforts are always needed from the apparatus itself.

Edi Santosa (Warsito and Teguh Yuwono, ed, 2003: 40) also added that the concept of capacity building, which is a manifestation of efforts to increase competence, which includes education and training for apparatus, is necessary to be implemented considering the urgency in the era of regional autonomy. With the existence of capacity building, each region is able to improve the capabilities and skills of its officials. If the apparatus's competence increases with the capacity building, it may improve their performance and productivity.

Thus, to analyse the capacity of Human Resources (HR) in a Regional Apparatus Organization (OPD) in the scope of the Malaka regency government, of course it cannot be separated from the capacity development itself in which individuals, organisations or institutions will be developed to carry out their functions, namely solving problems and set the achievement of goals (Suwartno, 2002: 121). Capacity building has multiple meanings and its interpretations depend on who is using it and in what context. In general, what needs to be understood is that capacity building is a concept that is closely related to education, training and the development of HR competencies itself.

The dimension of capacity development which is a concept regarding education, training and HR competency development can be explained by referring to Law Number 20 of 2003 concerning the National Education System which defines education as a conscious and planned effort to create an atmosphere of learning and the learning process so that students are actively developing his potential to have religious spiritual strength, self-control, personality, intelligence, noble character, and skills needed by himself and society.

In the management of the State Civil Apparatus itself, the restructuring of the state apparatus can be carried out through various kinds of efforts, including analysis of employee profiles related to organisational structure analysis; analysis of the profile of State Civil Servants who have met the qualifications for promotion; inventory and analysis of employee competency development needs that need to be improved; distribution of employees through job rotation based on organisational demographic analysis; distribution of employees who do not have a position; and expansion of duties, functions and authority through job enrichment. Thus it is hoped that this arrangement can fill the gap towards the ideal profile of the State Civil Apparatus and can optimise the capacity of each State Civil Apparatus.

In terms of its objectives, according to the Man Power Services Commissions (Faris, 2014: 5) it is explained that education is an activity that aims to develop knowledge, attitudes and skills, understanding and absorption of values needed in all aspects of life, not just knowledge and related skills to certain activities or jobs. Of the two concepts, each emphasises individual changes related to values, cognitive and psychomotor abilities through the development of self-potential in a planned manner. 
While the training itself can be described as an experience in learning prepared by organisations to improve employee performance (Nadler in Faris, 2014: 6-7). Operationally, training is an activity designed to help employees learn skills and behaviors to carry out their duties. Organisational goals can be achieved through work-oriented training at present or in the future (future orientation).

Education and training for apparatus can be used as a treatment for optimising organisational performance. Other than that, education and training for apparatus referring to Government Regulation Number 101 of 2000 concerning Education and Training for Civil Servants (PNS) also explains that education and training are processes of organising teaching and learning to improve the ability of the apparatus itself.

The apparatus's competence can be explained as the ability of knowledge, skills, and attitudes generally must be possessed by the apparatus in carrying out their duties, responsibilities, and authority in accordance with the competency standards of the position they have. For the apparatus to have the expected competencies, it is necessary to have appropriate and sustainable competency-based education and training. This means that competency-based education and training can be started from first being appointed as a Civil Servant until before retirement.

In general, the competency discrepancies of employees or organisational members are reviewed through existing employee competencies and compared with standard job competency standards as contained in the Strategic Plan (Renstra) in the field of Dismissal and Employee Performance Assessment Division Head. Thus, in its implementation, a competency standard is needed which contains an ideal reference about a set of knowledge, skills and attitudes that a person should have to do the job effectively. This is what is then called the competency standard for the field of expertise as a reflection of the competencies expected to be possessed by someone working in that field.

The mapping of competency in the field as described in Government Regulation Number 101 Year 2000 concerning Apparatus Education and Training, the institution, which is nationally responsible for the preparation of competency standards, is the institution controlling the training itself, namely the State Civil Service Agency. So, the practice of work competency standards for Civil Servants (PNS) in the work unit within the Malaka regency government must be carried out in collaboration between BKN and the relevant Ministries.

As a form of competency development for the apparatus, education and training play essential role in increasing competence, including integrity, responsibility, leadership, cooperation and flexibility in carrying out tasks. To achieve this goal, education and training must be carried out continuously (continuously). Of course, increasing human resources' capacity as a problem in this research must be carried out systematically and continuously. For this reason, it is necessary to have a synergic cooperation effort from each OPD in the scope of the Malaka district government with all stakeholders.

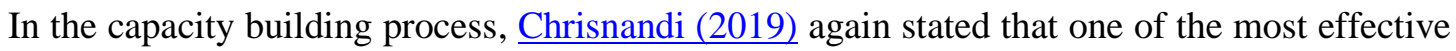
ways to improve building networks is to imitate how successful people interact with others (bkpsdmd.tanjabtimkab.go.id). However, please note that the imitation process is not easy (as long as it follows). But it also needs intelligence to identify various aspects related to the interaction process, such as how to control emotions, how to respect other people, how to talk, how to respond, and so on. Building a network is an art, so it is not easy to create a standard relationship pattern.

Another problem that cannot be ignored is the concept of good governance, when this concept can be read in its understanding as to the principle of universal authority (Kharisma, 2014) so that it becomes a necessity to be applied in governance in Indonesia, both at the central and regional levels. Meanwhile, to implement sound governance principles is inseparable from the bureaucratic problems faced by all Regional Governments in relation to human resource capacity, both in terms of structure and culture and the nomenclature of the programs support it. 
A very striking fact as evidence that good governance is still weak so far is the high practice of nepotism. Nepotism can be said to be rampant, especially among the bureaucracy in public institutions or government agencies, both departments and non-departmental institutions. In Malaka district itself, the issue of good governance is also a hot topic of discussion. Many problems violate the principles of good governance, including the placement of personnel in strategic positions. Paying attention to several examples of cases when someone who did not have the qualifications to occupy a particular position but was appointed as the Head or decision-maker in his institution further emphasises this.

In this context, it is a contrast that the principle of "the right man on the right place" seems neglected. It is commonplace when someone is appointed to a certain strategic position due to emotional closeness and closeness in other contexts which result in the professionalism of a position being neglected. In line with that, in this position, a Head of Regional Government and Head of OPD must be able to see his employees' ability or competence so that they can place him in a suitable position. This will affect performance if the staff does not have appropriate and appropriate competencies.

One simple conclusion that can be described as a representative of a case study of problems conceptually, empirically and normatively is to present an initial observation that the main problem faced by the Malaka Regency government as a New Autonomous Region (DOB) at all its current levels, among others, is weak capacity. Human Resources (HR) at both managerial and nonmanagerial levels and their role in carrying out their duties in government.

The Capacity Building for Local Government Toward Good Governance also exemplifies that the World Bank emphasises capacity building in 3 processes. The first processes are developing human resources through training, a transparent recruitment system, professional dismissal of employees, updating of managerial and technical patterns. Second, organisational development includes analysing the posture of the organisational structure based on roles and functions, the human resource development process, and management style. Third, networking development is carried out through strengthening coordination, clarifying the function of the network, as well as formal and informal organisational interactions (Eka A. Wibawa in Functional Lecturer at the Ministry of Law and Human Rights | Link: http: //bpsdm.kemenkumham.go. id).

Malaka Regency itself is one of the New Autonomous Regions (DOB) in East Nusa Tenggara Province, which was expanded in 2013 according to Law Number 3 of 2013 concerning the Establishment of Malaka Regency in East Nusa Tenggara Province. As a new district, one of the driving forces for the government is Human Resource. In accordance with the vision of the Malaka district 2016-2021, which is to lay a solid and dynamic foundation to achieve a prosperous Malaka community and one of its missions is to increase the human resources of the apparatus both in terms of number, type, quality/capacity and distribution. So HR Apparatus in this context is a priority program for realising the principles of good governance.

Until July 2019, the number of Civil Servants (PNS) in the scope of Malaka district was 3,376 PNS, of which 626 people or $18.5 \%$ worked in the office / agency / sub-district offices while the rest were educators (teachers) and health workers (https://ditjenpdt.kemendesa.go.id/p potential/district/54-kabamatan-malaka). In order to serve the administrative needs of these 3,376 people, especially personnel administration such as rank, career development and pension, it requires reliable resource capacity in each regional apparatus, especially the Head of Sub Division of Personnel. Given that the Head of the Sub Division of Personnel has strategic tasks such as carrying out general affairs, correspondence and archiving, data collection and processing, personnel administration, organisation and management.

In line with that, in September 2019 from 22 Services or Bodies of the Malaka district government, which consisted of 12 Sub Division Heads of Personnel (54.54\%). Definitely, it will result in personnel administration affairs, which are often hampered and coupled with the knowledge of the Head of the Sub Division of Personnel who is still minimal about personnel affairs because the placement does not match the basic knowledge concerned so that it has an impact on the minimum 
number of Civil Servants (PNS) who meet the requirements the standard or conditions for occupying the position in question.

In the implementation of tasks, there are many obstacles faced and carried out by the Head of the subdivision of personnel. According to information from the Malaka District Personnel and Human Resources Development Agency, in the process of personnel administration, the sub-division of personnel has been slow in responding to improvements and filing proposals. File verification, such as Employee Performance Targets (SKP), the Proposed Credit Score List (DUPAK) and Credit Score Determination (PAK) are not in accordance with statutory provisions. BKPSDM has provided improvements but the improvements are still wrong. In addition, the inaccuracy of accounting time is a problem that continues to be carried out by the Head of sub-division of personnel. The deadline for promotion proposals for the April period should be until mid-February but could be delayed until the end of February. Proposals for repairs are often submitted beyond the State Civil Service Agency's limit and result in the cancellation of civil servants from obtaining rank promotion decrees. Even in the pension files, there are many verification errors by the Head of the sub-division of personnel at SKP. Staffing regulations that change regularly are often not updated by the Head of the subdivision of personnel. Their knowledge is limited to what they know coupled with indifference to updating regulations related to main tasks and functions.

The human resource capacity in question can be read as the ability of a person or individual, an organisation (institutional), or a system to carry out its functions or authority to achieve goals effectively and efficiently (Winidyaningrum and Rahmawati, 2010: 24). According to Tjiptoherijanto in Alimbudiono and Fidelis, 2004: 431, to assess the capacity and quality of human resources in carrying out a function, it can be seen from the level of responsibility and competence of these resources. Based on this, this research proposal's preparation will begin by determining the title of the research, namely, "Improving the capacity of the Head of the sub civil service in regional apparatus organisation of the government Malaka district".

\section{Literature review}

\subsection{Human resources capacity}

An organisation's existence is strongly supported by the existence of three main pillars so that it can run well (Eka Ari Wibawa | Link: http://bpsdm.kemenkumham.go.id). The three pillars consist of good human resources, a good organisational structuring system, and business processes that are usually considered targets of organisational achievements in the vision and mission. Of course, the human resources aspect, both in terms of quantity and quality, can be seen in terms of knowledge, skills and attitude. From this, it can certainly be understood that capacity building is the process of increasing knowledge and skills, as well as attitudes and behavior.

It must be realised that the quality of human resources greatly influences an organisation's development in moving the organisation. Thus, the process of capacity building is an absolute must. In this process, it can be done in various ways, both through education and training (Diklat) and enhancing HR competencies by fostering clear career patterns and all of which are to improve the performance of organisational HR in carrying out their duties. Therefore, capacity development is closely related to human resource capabilities, institutional capabilities and organisational system capabilities.

\subsection{Definition of human resources capacity}

Definition of capacity Based on the opinion of Freddy Rangkuti (2013: 94) capacity is the optimum level of production capability of a facility. The definition of Human Resources or Human Resources contains two definitions. First, a work business or service can be provided in the production process (Sony Sumarsono, 2003: 6). Meanwhile, in other respects, HR reflects the quality of the business a person provides at a certain time to produce goods and services. The second definition, human resources concern people who can work to provide services or work businesses. Working means being able to carry out activities that have economic activities, namely that these activities produce goods or services to meet the needs or needs of the community. 
Another view also comes from Ruki (Edi Sutrisno, 2010: 5), who explains that Human Resources are resources that are in the form of and come from humans, which can appropriately be called human capital. Based on the above definition, it can be said that HR capacity is the quality of the business or the potential ability given by a person within a specific time to produce goods, services and integrated capabilities from the thinking power and physical power of the individual.

\subsection{Conception of capacity building levels}

Capacity development is not only oriented to human capabilities. Still, it includes the entire organisation's entire scope, which consists of an organisational structuring system or often known as a management system, a target policy, achievement strategies, and organisational regulations. This scope indicates a level of capacity development from capacity development or capacity strengthening, which means developing existing capacities and developing capacities that prioritise creative processes to build capacities that have not been seen (constructing capacity).

Therefore, capacity building is a process to carry out something or a series of activities to make multilevel changes in individuals, groups, organisations, and systems to strengthen the adaptability of individuals and organisations in facing existing environmental changes. For this reason, capacity building can be done through the process of analysing its environment, identifying organisational problems, looking for self-development and organisational needs, issues and opportunities that can be played by the organisation, formulating strategies in the process of overcoming problems and of course designing an action plan to collect data on the organisation system properly.

The Capacity Building For Local Government Toward Good Governance exemplifies that the World Bank emphasises capacity building on 3 processes. First, processes are human resource development through training, a transparent recruitment system, professional employee dismissal and updating of managerial and technical patterns. Second, organisational development includes analysing the posture of the organisational structure based on roles and functions, the HR development process, and the organisational management style. Third, network development is carried out by strengthening coordination, clarifying network functions, and formal and informal interactions.

\subsection{Capacity building}

Capacity building is a series of strategies to increase efficiency, effectiveness, and responsiveness of performance (Keban, 2000: 17). Meanwhile, Morison (2001: 42) sees capacity development as a process to carry out something or a series of movements, multi-level changes in individuals, groups, organisations and systems to strengthen the adaptability of individuals and organisations so that they can be responsive to changes in the existing environment.

Brown (Rainer Rohdewohld, 2005: 11) defines "Capacity building is a process that increases the ability of persons, organisations or system to meet its stated purposes and objectives". From this understanding, it can be interpreted that capacity development is a process that can increase the ability of a person, organisation or system to achieve the goals to be completed. According to Soeprapto (2006: 53), the definition of capacity development can be explained as follows:

a) Capacity building is not a product but a process.

b) Capacity building is a multi-level learning process covering individuals, groups, organisations and systems.

c) Capacity building links ideas to attitudes.

d) Capacity development can be referred to as actionable learning. Capacity development includes a number of interrelated learning processes, the accumulation of collisions that add prospects for individuals and organisations to adapt to change continuously.

According to Gandara (2008: 9), capacity building is a process to improve individuals, groups, organisations, communities and communities to achieve goals that have been implemented. Based on the explanation of the definitions of several experts on capacity development, it can be concluded that capacity development in general is a learning process in increasing the abilities, skills and expertise possessed by individuals, groups or organisations as well as systems to strengthen the abilities of individuals, groups and organisations so that able to defend themselves or their profession in the midst of changes that occur continuously. 


\subsection{Capacity building method}

Capacity building has its own activities that allow capacity building in a system, organisation, or individual, where these activities consist of several general phases. The phases according to Gandara (2008: 18) are:

a) Preparation Phase

In this phase there are 5 work steps, namely: (1). Identifying the need for capacity building, this work step has the main activity of identifying real reasons and needs for capacity building. (2). Set goals. This work step has the main activity of conducting consultations with key stakeholders to identify key capacity building issues (3). Give responsibility. This work step has the main activity of determining the person in charge of capacity building activities, for example forming a technical team or work unit (4). Designing a capacity building process. This kind of work step has the main activity of determining the mapping methodology according to the problems that arise and scheduling activities regarding the mapping process and formulating the capacity building action plan. (5). Allocation of resources. Its main activity is to identify funding for capacity building process activities and allocate resources by formulating resource requirements according to the required budget and approved by the authorities.

b) Analysis Phase

In this phase there are 5 work steps, namely: (1). Identifying the problem, in this case the main activity is examining the problem for further investigation. (2). Analysis of the process, in this case the main activity, is to link problems for capacity mapping with performance system processes, organisations and individuals. (3). In this case, organisational analysis is the main activity in selecting organisations to be investigated more deeply (organisational mapping). (4). Mapping GAP in this capacity, in this case the main activity, is mapping the gap between ideal capacity and reality. (5). Summarising the urgent capacity building needs in this case the main activity is to summarise the findings and collect proposals for a capacity building action plan.

c) Planning Phase

In this phase there are 3 work steps, namely: (1). Annual planning, the main activity is to formulate a conceptual capacity building action plan. (2). Making medium-term plans, the main activity of which is consultative meetings. (3). Developing a priority scale, the main activity of which is to determine the priority scale for capacity development and its implementation stages.

d) Implementation Phase

In this phase there are 5 work steps, namely: (1). Programming, the main activity is in the form of allocating the current resources. (2). Planning for capacity building projects, the main activity of which is to formulate a capacity-building implementation policy. (3). Selection of capacity building service providers, the main activity of which is to identify external services and products related to the implementation needs of capacity building to be carried out. (4). Project implementation, the main activity of which is implementing an annual capacity building program according to existing resources and available schedules. (5). Process monitoring, the main activity of which is to monitor capacity-building activities.

e) Evaluation Phase

In this phase there are 2 work steps, namely: (1). Impact evaluation, the main activity of which is to evaluate capacity building achievement, such as improving performance. (2). Re-planning the capacity building action plan, the main activity of which is to analyse the findings of process monitoring and impact evaluation in the context of the need for capacity building re-planning. 


\subsection{Capacity development pattern}

The term capacity building actually developed from the 1950s and 1960s to describe the community development process that focuses on increasing the capacity to master technology in rural areas. In the 1970s, UN agency reports emphasised the importance of building capacity for technical skills in rural areas and the administrative sectors of developing countries. At its center, in the 1990s, UNDP made the capacity-building movement a development concept to increase the empowerment capacity and participation of all organisational units.

Thus, the capacity-building work pattern emphasises all organisational components' equal involvement and the existence of open dialogue to agree to achieve organisational goals. An effective capacity process should encourage participation by all parties involved. If the stakeholders involved and all organisation members in formulating the achievement targets are involved, of course all of them will feel they belong to the organisation and will be more responsible for the results and sustainability of the organisation's achievements. Direct involvement of all components allows for quick and effective decision making, as well as more transparency.

Togetherness in developing capacity will also ultimately evaluate the achievement targets that have existed in the past, and allow capacity builders to see which sides need strengthening, which things must be prioritised, and of course, in what ways the achievement of targets will be carried out. Therefore, capacity building that is not initiated by a comprehensive study of organisational needs and an assessment of pre-existing conditions will generally only limit training. In contrast, according to the level of development it must cover all organisational components. There needs to be a capacity building evaluation to control organisational performance accountability through measurement based on changes in performance based on institutional arrangements, leadership, knowledge and accountability.

\subsection{Level of capacity development}

According to Soeprapto (2010: 54-55) that capacity-building efforts are carried out at various levels, namely capacity building must be carried out effectively and continuously at 3 (three) levels, namely:

1. System levels, such as frameworks relating to regulations, policies and basic conditions that support the achievement of certain policy objectives.

2. Institutional or overall level of units, examples of organisational structure, decision-making processes within organisations, work procedures and mechanisms, regulation of facilities and infrastructure, organisational relationships and networks.

3. Individual level, for example, individual skills and requirements, knowledge, behavior, job grouping, and motivation of people's work in the organisation.

\section{Research methodology}

The research method used in research was qualitative research methods with the type of case studies. The type of case study approach in qualitative research is the type of approach used to investigate and understand an event or problem that has occurred by gathering various kinds of information that are then processed to obtain solutions to resolve the problems expressed. 12 people were used as informants in this study. The 12 people are the Heads of Sub Division of Personnel at the Regional Apparatus Organization for the Malaka Regency Government

\section{Results and discussion}

\subsection{Capacity of head of personnel subdivision}

4.1.1. Education

Based on interviews conducted with informants, it was found that human resource capacity could not be developed due to the low educational qualifications possessed by the Head of Subdivision of Personnel in the Malaka District Government. Malaka Regency as a New Autonomous Region (DOB) urgently needs highly educated State Civil Servants (ASN) because higher education will also provide high performance in development. However, based on the confessions of the informants, it is also known that some, even though they do not have the education to support their position, the jobs and other tasks entrusted with them can still be carried out by the sub-division head. 
This is because of the experience in the field for a long time. However, the Heads of Subdivisions still have the desire and motivation to continue their education to a higher level such as undergraduate to master's degrees.

\subsubsection{Training}

In the provision of Technical Education and Training in accordance with position competencies, there were not many obstacles found. It's just that training (education and training) is not included routinely and tiered. This of course can have a negative impact on learning experiences that should be prepared by OPD to improve employee performance itself. Another factor that was also found was the absence of institutional reform. In fact, this institutional reform has had a huge effect on employee transfer from one particular position to another or what is commonly referred to as restructuring. With the employee restructuring, it will automatically build employee character, when an employee is required to adapt to a new environment so as to form a developing mindset. This shows that in terms of training the local government has made appropriate training efforts for its employees. This can be seen from the recognition of the informants who stated that the training materials were appropriate and dynamic in nature. however, the training did not have much impact on the employees. This is natural because the training is rarely carried out. This shows that the intensity of the training is not too high so that it gives the impression that the training is just a formality.

\subsection{Supporting factors and inhibiting factors capacity of head of personnel subdivision}

In carrying out the main duties as Head of Sub Division of Personnel, a sub-division head has many factors, supporting and hindering his duties. Supporting factors and Inhibiting Factors are as follows:

4.2.1. Supporting factors

1. Leadership Support

Leaders' role can support each other, facilitate members to work and maintain a commitment to realise organisational goals. Leadership support factors affect a person in carrying out their duties. Authoritarian leadership often makes subordinates not work optimally. Conversely, a good leader makes his subordinates work totally and achieve the desired targets. Based on the informants' admission, it was known that they would be able to complete various jobs and work constraints if they received support from their leaders. Leaders who assist tend to provide positive energy for employees to work well. This statement supports the theory, which states that the role of the leader in a work team can provide mutual support, make it easier for members to work, and maintain commitment for the realisation of organisational goals (Rivai and Mulyadi, 2012).

2. Subordinate Support

A leader is not alone in working. His subordinates in completing his main tasks and functions assist him. Leadership by nature, cannot walk alone. Leadership arises from collaboration with other people. Without other people, there is no leader. Leadership is not a one-man effort, but it involves teamwork. A reliable team is a team that can work together, trust and respect each other. Building a work team is to strive for the same vision, mission and goals to be achieved by continuing to brainstorm so that mutual agreement can be achieved (Rini: 2006). Leadership supporting factors influence a person in carrying out his duties. A good leader makes his subordinates work optimally and achieve the desired targets and this happens within the scope of the Malaka Regency organisation

\subsubsection{Inhibiting factors}

1. Regulatory Reform

Changes in laws and regulations, especially in personnel, often make the Head of subdivision of personnel find it difficult to complete their main tasks and functions, let alone rarely update information. This was admitted by the informant, who said that it was often too late to find out about several new regulations that were enacted. Besides that, other employees are not aware of some of the policy changes at the office. Changing the staffing regulations continuously plus new regulations makes it impossible for employees to study these laws one by one (Soeprapto, 2003). 
2. Lack of Education and Training

Changing regulations often make it difficult for employees to understand the content and purpose of these rules. Lack of creativity and innovation from humans as implementers of these regulations causes their understanding not to develop plus the lack of technical training related to main tasks and functions. From an informant, it is known that he has never even attended training that can help him improve his performance. This statement is almost the same for all informants except the PKPO office informant who has attended training for employee performance targets once. This is in line with the statement of Yuwono (2003), which states that the obstacle to developing human resource capacity is the lack of information about main tasks and functions. The resistance of a person exacerbates this where he or she is less dynamic and not positive in welcoming changes related to the development of their competence (Warsito and Yuwono, 2003).

\subsection{Steps taken in increasing the capacity of the Head of Sub Division of Personnel 4.3.1. Regional leadership support}

In supporting the increase in the capacity of the Head of the subdivision of personnel, the Regent of Malaka as a regional leader since 2016 in accordance with the main program, namely increasing human resources has taken strategic steps, namely:

1. Providing a budget and providing civil servants opportunities to continue formal education at tertiary institutions by granting study permits/assignments.

2. Providing a budget and sending civil servants who have held structural positions to attend government training institutions' leadership training.

3. Providing budget and member permits for civil servants to attend technical training and training according to their main duties and functions.

\subsubsection{Empowerment of Sub Division Heads}

In connection with the Head of Subdivision's empowerment within the scope of the Malaka district government, the interview session did not find an appropriate and systematic method that should be carried out. Among them is to assign tasks in accordance with the potential of the Head of Subdivision. For example, the tasks related to collecting, processing and identifying data based on input from each field to compile the database and statistics should be assigned to the Head of the Planning and Reporting Sub-Section.

The next method used to empower the competent Head of Subdivision is to provide feedback so as to motivate him to play an active role in carrying out his duties. Apart from the support from the BKPSDM of Malaka Regency, internally, the offices/ agencies/ sub-districts always provide room for the Head of the sub-division of personnel in his agency to develop self-competence. This support includes:

1. Giving permission to the Head of the sub-division of personnel to consult at BKPSDM Malaka Regency regarding employment matters.

2. Giving permission to the Head of Sub-Division of Personnel to attend personnel training.

3. Providing a means of accessing personnel information such as laws, government regulations and others online.

From this explanation, it can be concluded that there should not be many obstacles in empowering a competent Head of Subdivision. This is supported by a leadership factor where the leadership is open to giving opportunities to subordinates related to the implementation of tasks. However, the question then arises is "why does the Head of Subdivision of Personnel rarely or even never attend the training"?

Training in this position is an effort that is needed and must be carried out in the world of work. Whether new or already working, employees need to attend training because there are job demands that can change due to changes in the work environment, strategies, and other systems.

Through an in-depth interview, the research informant responded to the above question by answering that "does not know!" This then further emphasizes that training is not seen as a nomothetic dimension oriented to the demands of a regional government and the expected role of a Head of Subdivision according to the institution's objectives. Meanwhile, it is known that the training 
program contains formal academic elements. In other words, training is focused not only on the development of behavior alone but also on the behavior demanded by the world of work and personality development.

Another factor that supports the empowerment of competent employees is a mutual commitment. Where in this joint commitment is also a commitment that comes from superiors and subordinates. Commitment from superiors can be seen from leaders who are committed to continuously improving their employees' capabilities. Meanwhile, subordinates' commitment can be seen from a sense of full responsibility when the leader or superior gives an assignment.

According to Mathis and Jackson (2012: 5) definitively, training is a process where people achieve organisational goals through assessment, implementation and evaluation. Meanwhile, according to Bernadin and Russel in Gomes (2003) that training is an effort to improve employee performance in a certain company, which is their responsibility. Thus it can be concluded that activities designed to support optimal performance are always required for training. In a simple sense, training in this context can be viewed as a process within an agency to improve employee performance.

\subsubsection{Increased competence of the Head of Civil Servants}

Improving the quality of employees that is carried out will not be separated from the employees' competence. It must be in accordance with the standardisation system in each type and level of education (competency standards). The purpose of developing this competency standard is to determine a measure of the ability of knowledge and skills that must be mastered by an employee so that they are professional in planning and carrying out their duties and functions.

It is further explained by Bangun (2012: 210-211) that employee competency improvement can be done through in-service training programs. Training implies that after participating in training, an employee will be motivated by himself to improve performance. Given the Head of Subdivision's important duties, it is necessary to update the knowledge, insight, and skills towards the expected human resource capacity development.

It cannot be denied that in order to achieve the capacity of human resources in the Regional Apparatus Organization (OPD) within the scope of the Malaka Regency Government, an employee, in this case the Head of Subdivision, must always improve his educational and training abilities so that the principle of the right man on the right place is realised.

The concrete steps taken by the Malaka Regency Government are to give permission/study assignments and provide opportunities to attend personnel training. Thus, increasing the capacity of human resources needs serious attention. Competence improvement through education and training can be through in-service training programs (leadership, functional and technical). Ideally, a SubDivision Head participates in a training program at least once a quarter. This is based on two things. First, they can keep up with the rapid development of science and technology. Second, to provide opportunities for those concerned to meet the requirements for a promotion credit score or position.

\section{Conclusion}

1. The level of education of the staffing sub-section of the average senior high school (SMA) so that competencies need to be developed through providing opportunities to continue their education to a higher level

2. The Head of Civil Servants during the occupation of this position rarely even have never followed the training of technical staffing

3. In the main tasks and functions implementation as the Head of staffing, a supporting factor in supporting the success of work is the leadership and staff's support. Obstacles to the implementation of tasks are regulatory reform and lack of education and training

4. Steps were taken to increase the Head of the sub-division of staffing, namely providing opportunities to develop knowledge through formal education and technical education and training supported by the budget availability in each regional apparatus. 


\section{References}

Alimbudiono, Ria, S. dan Fidelis. (2004). Kesiapan Sumber Daya Manusia sub bagian akuntansi pemerintah daerah "XYZ" dan kaitannya dengan pertanggungjawaban keuangan daerah kepada masyarakat: renungan bagi akuntan pendidik. Jurnal Akuntansi dan Keuangan Sektor Publik, $5(2), 18-30$.

Bangun, Wilson. (2012). Manajemen Sumber Daya Manusia. Jakarta: Erlangga.

Brown, R. Rohdewohld. (2005). Measuring capacity building (carolina population centre). University of North Carolina: Chapel Hill.

Chrisnandi, H. Yuddy. (2016). Menuju Smart ASN 2019. Jurnal Pendayagunaan Aparatur Negara, 6 (6), 20-27.

Eka A. Wibawa. Fungsional Widyaiswara Kementerian Hukum dan HAM | Pranala: http://bpsdm.kemenkumham.go.id Eka A. Wibawa dalam Fungsional Widyaiswara Kementerian Hukum dan HAM. Pranala: http://bpsdm.kemenkumham.go.id

Faris, Ihsan Nur Iman. (2015). Investigating cultural contents of reading passages in the tests developed by English teachers in a senior high school. Jurnal Bahasa dan Sastra, 15(2), 239255.

Gandara, R. (2008). Capacity building dosen pada jurusan di perguruan tinggi Badan Hukum Milik Negara. Skripsi Sarjana pada Fakultas Ilmu Pendidikan UPI Bandung: Unpublished.

Gomes, F. C. (2003). Manajemen Sumber Daya Manusia. Edisi Kedua. Yogyakarta : Andi Offset.

Hasibuan, Malayu. S.P. (2003). Organisasi dan motivasi dasar peningkatan produktivitas. Bumi Aksara: Jakarta

Keban, Yeremias T. (2008). Enam dimensi strategis administrasi publik: konsep, teori dan isu. Gava Media: Yogyakarta.

Kharisma, B. (2014). Good governance sebagai suatu konsep dan mengapa penting dalam sektor publik dan swasta: Suatu pendekatan ekonomi kelembagaan. Jurnal Buletin Studi Ekonomi, 19(1), 1-34.

Mathis, Robert L. dan John H. Jackson. (2012). Manajemen Sumber Daya Manusia. Edisi Pertama Salemba Empat, Jakarta.

Morrison Tarrance. (2001). Actionable learning-a handbook for capacity building through case based learning. ADB Institute.

Pemerintah Daerah Kabupaten Malaka. (2016). Peraturan Daerah Nomor 81 Tahun 2016 tentang Organisasi Perangkat Daerah (OPD) Kabupaten Malaka. Sekertariat Kabupaten Malaka.

Pemerintah Republik Indonesia. (2014). Undang-Undang Nomor 23 Tahun 2014 tentang Pemerintah Daerah. Lembaran Negara Republik Indonesia Tahun 2014 Nomor 244. Sekertariat Negara. Jakarta.

Pemerintah Republik Indonesia. (2013). Undang-Undang Nomor 3 Tahun 2013 tentang Pembentukan Kabupaten Malaka di Provinsi Nusa Tenggara Timur. Lembaran Negara Republik Indonesia Tahun 2013 Nomor 18. Sekertariat Negara. Jakarta.

Pemerintah Republik Indonesia. (2003). Undang-Undang Nomor 20 Tahun 2003 tentang Sistem Pendidikan Nasional. Lembaran Negara Republik Indonesia Tahun 2003 Nomor 78. Sekertariat Negara. Jakarta.

Pemerintah Republik Indonesia. (2000). Peraturan Pemerintah Nomor 101 Tahun 2000 tentang Pendidikan dan Pelatihan Pegawai Negeri Sipil. Lembaran Negara Tahun 2000 Nomor 198. Sekertariat Negara. Jakarta.

Rangkuti, Freddy. (2013). Teknik membedah kasus bisnis analisis SWOT cara perhitungan bobot, rating, dan OCAI. PT. Gramedia Pustaka Utama: Jakarta.

Rini, W. A. (2006). Kepemimpinan yang membangun tim. Jurnal Ekonomi Modernisasi, 2(2), 66-75.

Rivai, Veithzal., \& Deddy Mulyadi. (2012). Kepemimpinan dan Perilaku organisasi Edisi Ketiga. Jakarta : PT. Rajagrafindo Persada.

Sumarsono, Sonny. (2003). Ekonomi manajemen Sumber Daya Manusia dan ketenagakerjaan. Graha Ilmu: Yogyakarta

Sutrisno, Edy. (2010). Manajemen Sumber Daya Manusia. (cet. III). Kencana Prenada Media Group: Jakarta.

Suwartno. (2002). Manajemen modern: teori dan aplikasi. Bandung :Zafira. 
Soeprapto, R. (2003). Pengembangan kapasitas pemerintah daerah menuju good governance. Jurnal Ilmiah Administrasi Publik FIA Universitas Brawijaya, 4, 2003.

Teguh, Ambar dan Rosidah. (2009). Manajemen Sumber Daya Manusia: konsep, teori dan pengembangan dalam konteks organisasi publik. Graha Ilmu: Yogyakarta.

Warsito dan Teguh Yuwono, ed. (2003). Otonomi daerah: capacity building dan penguatan demokrasi lokal. Puskodak UNDIP: Semarang.

Winidyaningrum, Celvina, dan Rahmawati. (2010). Pengaruh Sumber Daya Manusia, dan pemanfaatan Teknologi Informasi terhadap keterandalan dan ketepatwaktuan pelaporan keuangan pemerintah daerah dengan variable intervening pengendalian intern akuntansi: studi empiris di Pemda Subosukawonosraten. Simposium Nasional Akuntansi XII, Purwokerto. 